\title{
'Explode All Our Metaphors' - On the Potential of Sound in Media and Audience Studies. An Interview with Martin Barker
}

RAFAL ZABOROWSKI, London School of Economics and Political Science

\begin{abstract}
In this interview Martin Barker discusses his recent studies concerning audience experiences of organised sound. Complicating a multi-sensory approach, he engages with a number of contested notions in the field, such as liveness or visualisation, and suggests that empirical work is necessary to better understand what they mean for the audiences - but methodologically, such empirical work is not without challenges. Reviewing a number of interdisciplinary publications, Barker argues that research of sound can help open up the field of audience studies, but to do that, we need a careful, historical analysis of sound audiences across time and place.
\end{abstract}

\section{KEYWORDS}

Music; Sound; Audiences; Liveness; Listening; Methodology; Modes; Multi-Sensory Approach 
RAFAL ZABOROWSKI: Martin, we are talking today because you are an expert in the field of audience research and it is always great to get your insight. I wanted to ask you about music, about sound and listening within the history of audience research, as you see it. But more specifically, we are also here to talk about listening in the context of a paper on audience responses to opera, which you presented quite recently (Barker 2014), and another one you will present soon (Barker 2015).

MARTIN BARKER: Thank you for the compliment. The context in which this came was the work that I did on people coming to 'livecast' or 'simulcast' cinemas (Barker 2012) and thinking about the circumstances in which people regard something as being live to them. There are all kinds of debates about 'liveness', as you well know, and when I was doing my background work on this, what really struck me was that I could find 7 or 8 different traditions for thinking about 'liveness', but they didn't correspond to what I actually heard when I talked to or questionnaired people about what it meant to them to go to these livecast events. Taking just one illustration, which to me is an important one because it shows that theories about 'liveness' aren't just things that academics work with. One of the things that struck me hearing audiences talk about their reactions to livecasting was many people's surprise at finding that they still enjoyed performances, even though they weren't 'there' where it happened. Even, lots of people were surprised to find that it was better than being there. They were able to listen better. So, they had expected that 'liveness' in the sense of presence would matter to them, but it turned out that it didn't.

RZ: As far as audiences are concerned and audience research is concerned, there is relatively not that much about listening. However, where there is, we have on the one hand a body of research done in context of music events, attending concerts, performances. And on the other hands we have had some attempts to place music and listening within everyday life. And it seems to me that in studies of music these two spheres are still very much separate, while in audience research we had such debates a bit earlier; debates where we said that perhaps these are not two different things, these are all a part of a spectrum, they are both on the spectrum of audience engagement.

MB: I do totally agree with what you said, but my concern coming out of film audience research, more than anything else, is that music may not be a thing distinct from other kinds of sound effects within cinema. I remember when we were doing interviews with people after the Lord of the Rings project, I became very curious about how a lot of people wanted to talk about the issue of 'visualisation'. Now, there is a long tradition of theorising 'visualisation', but what I found when I talked to people was that they talked about it differently. One quotation in particular jumped out for me. There was this one guy who had loved to see Lord of the Rings, because he'd loved the books, but the books had left him with gaps. And the films 'completed' the story for him - and there was an emphasis on the word 'completion', it was like this was a jigsaw waiting for extra bits to be added in. So, he was looking for completion. But then he said something really interesting, talking about visualisation. He said: 'It helped me visualise things that I hadn't been able to do before, especially the sound.' And I thought, hang on, visualisation sounds like it's entirely to do with the eyes. And you are not doing it that way. You are saying that visualisation is a conceptual completion of the world you've created, which absorbs how the music is chosen, the radical sound effects construction. And they are all absorbed in this panoply of things called visualisation. That set me thinking more broadly about 'visualisation' as a working concept among audiences. 
Another example. When I was preparing the talk for the 'Listening Cinematically' conference, I revisited our Lord of the Rings database, looking for everyone who talked about sound and music, and I found this fascinating response from a woman who loved the way that the films built up a strong sense of the different cultures in Middle-earth. And for her the music - even if it was entirely extra-diegetic - became a sort of evidence of the nature of the worlds they went with - proving (her words) that in Middle-earth 'the arts are just as important to the world as anything else'. That's really complicated, and that is one of the things that I love about the contributions that audience research makes. It messes up our tidy categories!

And I do think there is something interesting there about audiences, especially when they really become engrossed in something like a film, working at completing an experience. And I guess this connects with something I am interested in general: how intellectually and analytically we all mark the separations between various strands and facets of sounds. The dialogue, the ambient sound, the extra-diegetic sound, the music, all those that we (as academics) separate, because it's helpful to us for thinking how they are put together. In terms of other audiences, I don't think they necessarily make those separations - not if they work effectively for them. People will generally separate out something if they feel it's redundant or excessive or irrelevant to the 'whole' that they're making. If it works, it is a composite, a completion, it's a 'visualisation'. If not, they may separate in order to criticise.

RZ: On the other hand though, the more musicologist attempts are really trying to theoretically and conceptually separate the different modes in which we listen. I think we both read Listening in Paris (Johnson 1996) and that book starts with a question of how the audiences became silent, how the mode of engagement, mode of listening changed.

MB: It's interesting you say that, Rafal, because you've picked up on the thing a lot of reviewers picked up on. And I agree this is a tremendous book, it's a wonderful book, but to me that point about the emergence of silence was not the most striking. To me the most striking thing was when he talks about the ways in which certain composers shifted from being seen as incomprehensible, marginal and useless - to being worshipped. Beethoven was the key example. In 1810 he is dismissed: 'please no, do we have to listen to Beethoven?' Then 20 years later Beethoven is this absolute triumphal figure around whom there is this god-like aura. Although Johnson doesn't fully explain it, he demonstrates how this change had taken place: because of and through the coming of silence, but more than that, because almost of a reorientation of peoples' ears, of how they listened. That to me was the most striking thing about the book: it was that sense that the forms of music and how they engaged people's brain cells and listening capacities and so on - these shifted over time. So there were the formalities in the 1770s' music, and then the breakdown of those as you approach the revolution and people celebrating the breakdown - and then going 'oh my god what have we done, we've got a revolution on our hands!'

And that to me was more interesting than just the move to silence. That's just the kind of formal, external aspect of the changes. Does this make sense?

RZ: Absolutely it does and I found it interesting, too, because the book does many things the 'audience research way', as you like. In a way that it includes structure and agency, and talks about audiencing as if the meaning is not set in-text not in the composer's intentions, but through listening, through the mode of reception, which is socially and aesthetically and historically influenced, and that all is where the interpretation takes place, where meaning is 
made. Which is in a way still a rare way of talking about listening, I think, and a very comprehensive view.

MB: Yes, the only other place I found this is a book you might know already, Claudio Benzecry's The Opera Fanatic (2011), which blew me away when I read it. I thought it was a fantastic piece of work. It's a study of one particular opera house in Buenos Aires. Not simply the opera house in its entirety, though he does talk about the architecture and the history, and the production traditions in this house. But it's most particularly the study of one particular group in the audience who inhabit one of the upper circles (where it's not too expensive), who are very particular about their mode of listening, incredibly knowledgeable, fiercely protective of their experience, and will spend large amounts of money to get out what they want, but equally say that it has to be perfect for them to expend that money. And it's partly about the manners of how they do this. So, for example, they hardly know each other outside the opera house, yet they recognise themselves the moment they get there: 'These are my kind of people'. And then, the moment the music starts they close their eyes and go into a mode of listening which is simultaneously utterly absorbed and utterly critical. It's a hardwon achievement to get that intense, loved experience that they want. If it's missing, they're angry. So it's also about their ways of complaining at the loss of it; they see it as a form of something being stolen from them - that the stars aren't right, or the music isn't right - even though they are not even positioning themselves in the best place to get the music, because they're in the third tier. But that's where they chose to go and that's where they habitually go. Right at the end of the book he goes beyond this just being about opera to ask: is there a politics in this? He talks about a conservative turn in Argentinian politics. And they are part of this conservative turn, where the loss of this is a symbol of the loss of other things going on within Argentina. It's a really fascinating book.

RZ: It's interesting, because we have talked a lot about opera, and opera is so visual, too. And the closing of the eyes reminded me of Pierre Schaeffer and Michel Chion, and of how musicologists talk about the attentive modes and non-attentive modes. And this goes back to the acousmatic music, the akousmatikoi, to Pythagoras who had a curtain, so that his students wouldn't see him speaking and it wouldn't distract them from the content of his teaching. Which is how, I think, many later writers thought. Adorno, for example, had those eight listener types and he very clearly put some value in them, and on the top there is the well-informed, reflexive, expert listener.

MB: Right. So a visual component would be a definite distraction, stopping 'proper listening'

RZ: Right, and we can go back to Plato and the very visual metaphor of a cave where sound is a distraction. I think we haven't got over this in studying sound. Somehow, when we study television and opera, we forget about the sound, but whether include them or not this doesn't seem as such a big deal. However, when we research just the sound then we don't know what to do with the visual. Not sure if you agree?

MB: Well yes, I think I do agree. I guess my approach is, I'm leaning towards a multisensory approach, but accepting that this will work differently for different parts of audience and maybe for individual manners in the audience. Let me relate a personal experience. I cannot generally listen to classical music in a concert. I find it intensely distracting to see the players. But if I'm listening to jazz, I like to be with them and see them.

RZ: Right, I can understand that. 
MB: So, there is something about my mode of attention to each which is starkly distinct. If I am listening to film music it is very rare for me to hear film music out of the context of the film in the same way and for it have anything like the same resonance. Once or twice I've come close to it, with the film The Insider for example, where the music is fascinating in its own right, but that's rare. Or Donnie Darko, where there's something weird about the music of Donnie Darko, it has a life of its own which I'm happy to listen to.

RZ: I agree.

MB: So, I'm arguing, inevitably I'm taking account of audience perspectives to this, that it seems to me that both by the nature of the audience and by the mode with which they are engaging, we should look for and expect variation in the kind of attention people want to give. So, the one occasion in which I actually went to a classical concert and was bowled over was a performance of my all-time favourite piece of music, Mahler's Second Symphony, for which I have a passion. For my birthday one year my wife took me for a concert of it, and we arrived late so we got 'bad' seats - we were right behind the trumpets. And there's a point at the end of the First Movement where the music becomes dissonant for several bars until he suddenly lets the trumpet snarl and the whole thing resolves ... And there was such viscerality to it, it was beyond sound, it was whole-body. And that was just extraordinary, it was orgasmic, it was so powerful.

And I think I would argue that the mistake for musicologists is to go for that motion of the pure music experience. There are moments and occasions for some kinds of people that are pure music experiences, but historically we know that's unusual. For many people music's tied in with dance, with movement, with joining in. On other occasions you do get that zone of silence - but you are looking! - unless you are one of those people in that opera house in Buenos Aires, where you go for a particular kind of intense engagement: 'who's down there? We don't like them. Oh god, it's her, we're in trouble today... Close my eyes.'

RZ: Thinking about sound in this way, I wonder whether some of the conceptualisations we use in audience studies, for engaging with media, like, for example (Liebes and Katz's) the referential and the critical, do not quite work in listening.

MB: It doesn't work, does it?

RZ: We can take the glance and gaze and wonder whether we could talk this way about listening and hearing, and so on, but overall the conceptual repertoire fails when we talk about music. How do we talk about music, how do we talk about listening that is helpful for audience studies?

MB: it took us a long time to get past the dominant metaphor, the visual, the cinema gaze. It took a long time for us to realise what a distraction that was, and what a block it was to understanding what audiences actually do and how they relate to things like films. The interesting thing about music or, rather, organised sound (as I would prefer to call it) is that, because it's not mode-specific, you find it in many other forms, ways and media than just through film or television. It has its own life as discrete media, it also appears in communal dance events and so on. It has all those different modes. It has the potential, it seems to me, to explode all of our metaphors when talking about audiences. 
There was a short phase, it must be about a decade ago, when a number of people became fascinated with the idea of how many senses we have. We have traditionally talked about five senses, but then gradually we realised there's not five, there are more like 23 actually. By the time you take in vibration, heat, erotic arousal and so on, you go through them all and you go: it's not five senses, there's an awful lot that we have. And there was for a time an interest in that, and I wonder whether the way in isn't through asking, as people listen to organised sound, what parts of their sensory apparatuses are stimulated, brought into action.

The fact is that when people listen to different kinds of music, it's very, very hard to sit still, you feel your body begin to move in response. You are doing more than listening with your ears. You are listening with the potential of your body movements. That's really important! Because if you try to suppress it then music loses half its meaning, half its affect. That's why I'm inclined to call it organised sound rather than music. Because the term 'music' is freighted with so many pre-existing meanings.

RZ: And to investigate that, I think we both agree, asking the audience is hugely useful. However, not everyone does. My personal anecdote about this is being at a non-audiencecentric conference, be it a music conference or an area studies conference, and I am hearing the questions that television studies scholars were asked some time ago. 'Well how can you ask the audience about their experience when they don't have the vocabulary to tell you about it? They don't know what timbre is, they don't know the pitch and so on. They can't tell you what is happening in the music they're hearing.' Which is of course not really what we are interested in. But I think that these debates are very much alive outside our audience bubble.

MB: I think that's right. And my suspicion is that musicology rather like theatre studies is too close to the professionals. In theatre studies there has been this notable problem that in effect when people study performance they are looking with an eye to being directors themselves. They are writing professional reviews. Interestingly for a long time in film studies the opposite was true: film scholars liked the idea of film but they didn't trust filmmakers, so they were writing always with an eye to the ideologies that might be being smuggled through. And therefore scholarship was suspicious, and wanted its own language, not theirs. What audience research does, it seems to me, is to say we can't just have our own language. What we need is the methodologies for gathering other people's languages. How do they organise their terms? How do they live out their own experiences of this? Mind you, I don't deny that this is a huge methodological challenge, because people don't always have overt languages for doing things, and sometimes you sometimes have to come in sideways and say for instance (I am making this up now), 'Here's two bits of music that I know you like. What are you doing when you listen to it? What's going on inside you?' And you can kind of think, we can get inside their responses if we can get people to struggle with their own languages, and get as far as they are able to overt expression of their feelings.

RZ: That's a great point. The methodological challenge has started to be recognised, I think, and there might be a bit of a shift and an interesting in music in sound within media studies. We talk about the musical assemblage (see Born 2005), the ubiquitous listening (see Kassabian 2013), the background and foreground listening in ways we haven't before. But with listening that has no modes, no foreground - the challenge of that is then: how do we investigate this? I'm not sure. 
MB: Nor am I. and I have never really tried to do it - it just emerged as a topic in some of the research I'm doing. I had a $\mathrm{PhD}$ student, Lauren Anderson, who took a romantic comedy which used a lot of songs, and she showed it to groups of people asking what they saw the music contributing to the film, how it was integrated with the film (Anderson 2012). And one of the first things she encountered was that some people said they didn't even realise it was there. They hadn't segmented it, they couldn't layer it out. And importantly those were the people who loved it the most. So often, it seems, when people love something, they don't separate it out. The people who thought it was 'alright - but the music went on a bit', they lifted it out as a separate layer to be examined and heard on its own, but therefore didn't see it as contributing much to their whole experience of the film.

RZ: So, rounding up, is music up for grabs in audience studies?

MB: Yes, absolutely!

RZ: Looking back the history of audience studies, what can listening bring to the field? This is not anymore a new field, it is an established field, but still perhaps it's not that focused on sound, on music?

MB: That's a really interesting question. I don't think there's anything in it of it itself utterly distinctive. But because of the way this topic has historically grown, I'd see it rather like the way in which Robert Darnton's work opened up the field of reading. Do you know his book The Great Cat Massacre (1999)? The leading essay in this was a study of how and why it was that in Paris in $17^{\text {th }}$ century apprentices used to make a point of catching, torturing, putting on trial and ultimately killing their employers' cats. $\mathrm{He}$ is fascinated by this phenomenon, although we know very little about it and there are only fragmentary records. He tracks back through the fragments of evidence to produce a very convincing explanation as to why, in that point in time, it was a form of political revenge played out on a cultural level.

At the same time he also has very interesting essays in his book about, for example, people reading Rousseau. People were learning: 'hang on, I'm going to have to read this book in a way I have never read it before'. It demands a different kind of attention. Therefore it's about the way in which the manners of attending to cultural objects have changed over time. Now, because of the way in which musicology has grown around this (and I'm thinking of things like Listening in Paris), there is a way of accessing the history here. We have so little evidence of the detailed history of cinema audiencing. We have even less evidence on radio listening. And so on.

So as opposed to the modern media we have these possibilities of longer histories. And when you have a long history you can end up looking at the present in a different way. So I think that listening studies could perhaps benefit from that and achieve something through that. Whereas cinema studies or audience studies in cinema are almost entirely constrained to being snapshot after snapshot, rather than: 'look at this trend over time, look at this change happening here' and think the implications for us today.

There's another wonderful book actually which has just occurred to me, which is again not just about listening. It's a book about the period 1880 to 1925 in European theatres (Blackadder 2003). And it's about the fact that in that period a whole succession of theatre riots took place. Neil Blackadder, its author, goes back to the documentary records to ask 
why in that period people's expectations of theatre got fundamentally disturbed. Literally, minute-by-minute in the theatre: 12 minutes in one of the actors said something on stage, and the audience went 'Oof' - and he catches it. And then what the theatre manager did to try and stop the stamping on the floor. And when the police were called. And how people who led the protest then wrote their diaries about it. It's a fantastic piece of research. So it's about those moments when manners get disturbed, in a way which reveals what the manners were. It's harder to see them when they just seem normal. When they are normalised we don't generally think about them - it's when they're strained and stressed that they become visible to us.

That's why I have long believed that as a research technique with audiences one really productive way is to pursue when people are disappointed. Because when they're disappointed, they call up in their talk what it was they hoped for...

RZ: ...their expectations.

MB: ...hopes and expectations. Their mini-ideals.

RZ: Which I think is clear in music studies too. We all have such very strong expectations about what we listen to. What we expect the next album of our favourite artist to be and how we can be disappointed when it's not the way we had hoped.

MB: Yes, yes, I think so.

RZ: I think we ended on a gloomy note, talking about disappointment, but this has been hugely useful, Martin. Thank you so much for your time.

MB: It was my pleasure.

\section{References}

Anderson, L. (2012) '“That's How it's Supposed to Make You Feel”: Talking with Audiences about "Both Sides Now" and Love Actually", Participations, 9(2).

Barker, M. (2012) Live To Your Local Cinema: The Remarkable Rise of Livecasting, Basingstoke: Palgrave Pivot.

Barker, M. (2014) 'Distinct/Distinctive: What Opera Audiences Take To and From Cinema Simulcasts', presented at Opera and the Media of the Future, 24-25 October 2014, Glyndebourne Opera and the University of Sussex, UK.

Barker, M. (2015) 'You Sort of Listen with Your Eyes: How Audiences Talk About Film Music', presented at Listening Cinematically, 25-26 June 2015, Royal Holloway, University of London, UK.

Benzecry, C. E. (2011) The Opera Fanatic: Ethnography of an Obsession, Chicago: Chicago University Press. 
Blackadder, N. (2003) Performing Opposition: Modern Theatre and the Scandalised Audience, Westport: Praeger.

Born, G (2005) 'On Musical Mediation: Ontology, Technology and Creativity’, Twentieth-Century Music, 2(1), 7-36.

Darnton, R. (1999) The Great Cat Massacre and Other Episodes in French Cultural History, New York: Basic Books.

Johnson, J. H. (1996) Listening in Paris: A Cultural History, Berkeley and Los Angeles: University of California Press.

Kassabian, A. (2013) Ubiquitous Listening: Affect, Attention, and Distributed Subjectivity, Berkeley: University of California Press.

Martin Barker is Emeritus Professor at Aberystwyth University. He has published extensively across the field of media and cultural studies, focusing on film audiences in the last two decades. He was principal investigator in the International Lord of the Rings project (2003-2004) and he now leads The World Hobbit Project, which is a cross-cultural, multicountry investigation into audience engagement with film and the role of fantasy in contemporary culture. Martin founded and now co-edits the online journal of audience and reception studies, Participations (www.participations.org). 